Giorgio Scagliotti and Silvia Novello, University of Turin, Orbassano, Torino; Adolfo Favaretto, Istituto Oncologico Veneto, Padova; Armando Santoro, Istituto Clinico Humanitas, Milan, Italy; Joachim von Pawel, Asklepios-Fachkliniken MünchenGauting, Munich, Germany; Rodryg Ramlau, Poznań University of Medica Sciences, Poznań, Poland; Fabrice Barlesi, Aix Marseille University, Assistance Publique Hôpitaux de Marseille, Marseille, France; Wallace Akerley, Huntsman Cancer Institute, Salt Lake City, UT; Sergey Orlov, St Petersburg State Medical University, St Petersburg, Russian Federation; David Spigel, Clinical Locations, Nashville, TN; Vera Hirsh, McGill University Health Centre, Montreal, Quebec; Frances A. Shepherd, Princess Margaret Cancer Centre, Toronto, Ontario, Canada; Lecia V. Sequist, Massachusetts General Hospital, Boston; Jeffrey S. Ross, Foundation Medicine, Cambridge: Brian Schwartz, ArQule, Woburn, MA; Alan Sandler, Genentech, San Francisco, CA; and Qiang Wang, Reinhard von Roemeling, and Dale Shuster, Daiichi Sankyo, Edison, NJ.

Published online ahead of print at www.jco.org on July 13, 2015

Support information appears at the end of this article.

Authors' disclosures of potential conflicts of interest are found in the article online at www.jco.org. Author contributions are found at the end of this article.

Clinical trial information: NCT01244191.

Corresponding author: Giorgio V Scagliotti, MD, Department of Oncology at S. Luigi Hospital, University of Torino, Regione Gonzole 10, 10043 Orbassano, Torino, Italy; e-mail: giorgio .scagliotti@unito.it.

๑) 2015 by American Society of Clinical Oncology

0732-183X/15/3324w-2667w/\$20.00

DOI: 10.1200/JCO.2014.60.7317

\title{
Phase III Multinational, Randomized, Double-Blind, Placebo-Controlled Study of Tivantinib (ARQ 197) Plus Erlotinib Versus Erlotinib Alone in Previously Treated Patients With Locally Advanced or Metastatic Nonsquamous Non-Small-Cell Lung Cancer
}

Giorgio Scagliotti, Joachim von Pawel, Silvia Novello, Rodryg Ramlau, Adolfo Favaretto, Fabrice Barlesi, Wallace Akerley, Sergey Orlov, Armando Santoro, David Spigel, Vera Hirsh, Frances A. Shepherd, Lecia V. Sequist, Alan Sandler, Jeffrey S. Ross, Qiang Wang, Reinhard von Roemeling, Dale Shuster, and Brian Schwartz

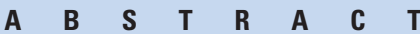

\section{Purpose}

Tivantinib, a MET receptor tyrosine kinase inhibitor, demonstrated increased anticancer activity in preclinical and early clinical studies when combined with erlotinib. Our study aimed to confirm efficacy and safety of the combination in previously treated patients with non-small-cell lung cancer (NSCLC).

\section{Patients and Methods}

Patients with advanced nonsquamous NSCLC previously treated with one to two systemic regimens, including a platinum doublet, were randomly assigned at a 1:1 ratio to receive erlotinib $150 \mathrm{mg}$ daily plus oral tivantinib $360 \mathrm{mg}$ twice daily $(E+T)$ or erlotinib plus placebo $(E+P)$ until disease progression. Tumor specimens were evaluated for EGFR and KRAS mutations, MET expression, and MET gene amplification. The primary end point was overall survival (OS). Secondary and exploratory objectives included progression-free survival (PFS), OS in molecular subgroups, and safety.

\section{Results}

The study enrolled 1,048 patients and was discontinued for futility at the interim analysis. OS did not improve with $\mathrm{E}+\mathrm{T}$ versus $\mathrm{E}+\mathrm{P}$ (median OS, 8.5 v 7.8 months, respectively; hazard ratio [HR], $0.98 ; 95 \% \mathrm{Cl}, 0.84$ to $1.15 ; P=.81$ ), even though PFS increased (median PFS, $3.6 \vee 1.9$ months; $\mathrm{HR}, 0.74 ; 95 \% \mathrm{Cl}, 0.62$ to $0.89 ; P<.001)$. Exploratory subgroup analyses suggested OS improvement in patients with high MET expression ( $\mathrm{HR}, 0.70 ; 95 \% \mathrm{Cl}, 0.49$ to 1.01). Most common adverse events occurring with $\mathrm{E}+\mathrm{T}$ versus $\mathrm{E}+\mathrm{P}$ were rash $(33.1 \% \vee 37.3 \%$, respectively), diarrhea $(34.6 \% \vee 41.0 \%)$, asthenia or fatigue $(43.5 \% \vee 38.1 \%)$, and neutropenia (grade 3 to $4 ; 8.5 \% \vee 0.8 \%$ ).

\section{Conclusion}

E + T was well tolerated and increased PFS but did not improve OS in the overall nonsquamous NSCLC population.

\section{J Clin Oncol 33:2667-2674. (C) 2015 by American Society of Clinical Oncology}

\section{INTRODUCTION}

Lung cancer is a leading cause of cancer-related death, with approximately 1,825,000 new patient cases and 1,590,000 deaths worldwide in $2012 .^{1}$ Non-small-cell lung cancer (NSCLC) represents $85 \%$ of all lung cancers. ${ }^{2}$ For patients with locally advanced or metastatic disease, systemic chemotherapy provides a modest but statistically significant improvement in survival. ${ }^{3}$ In the last 15 years, clinical research efforts with targeted agents have endeavored to improve survival beyond cytotoxic chemotherapy.

Overexpression of the N-methyl- $\mathrm{N}^{\prime}$ nitrosoguanidine human osteosarcoma transforming gene $(M E T)$ or aberrant signaling of MET receptor tyrosine kinase occurs in lung cancer and other solid tumors. The involvement of MET in multiple signal transduction pathways affecting tumorcell proliferation, mobilization, and angiogenesis 
makes it an interesting potential target for cancer therapy. ${ }^{4-6}$ Tivantinib (ARQ 197; ArQule, Woburn, MA; Daiichi-Sankyo, Tokyo, Japan) is an orally available selective small molecule that inhibits MET receptor tyrosine kinase with a novel ATP-independent binding mechanism, leading to inhibition of cell proliferation and induction of apoptosis in MET-expressing cancer cells. ${ }^{7,8}$ Although epidermal growth factor receptor (EGFR) tyrosine kinase inhibitors have shown higher therapeutic activity when EGFR-sensitizing mutations are detected, ${ }^{9}$ the EGFR inhibitor erlotinib (Tarceva; Genentech, San Francisco, CA) has demonstrated efficacy in previously treated patients with advanced NSCLC. ${ }^{10,11}$ Consequently, dual inhibition of MET and EGFR with the combination of tivantinib plus erlotinib was a rational approach to be explored in advanced NSCLC. A randomized phase II study of tivantinib plus erlotinib versus erlotinib alone in 167 patients with chemotherapy-pretreated, EGFR inhibitor-naive advanced NSCLC showed trends toward improved progression-free (PFS) and overall survival (OS) in the nonsquamous NSCLC subpopulation and improved PFS in the EGFR wild-type (WT) and KRASmutant subpopulations. ${ }^{12}$ The objective of this phase III randomized, double-blind, placebo-controlled study (MARQUEE [ARQ 197 Plus Erlotinib Versus Placebo Plus Erlotinib for the Treatment of NonSquamous, Non-Small-Cell Lung Cancer]) was to confirm the efficacy and safety of tivantinib plus erlotinib versus erlotinib plus placebo in previously treated patients with locally advanced or metastatic nonsquamous NSCLC. ${ }^{13}$

\section{PATIENTS AND METHODS}

\section{Patients}

Eligible patients were adults age $\geq 18$ years with histologically or cytologically confirmed, locally advanced or metastatic (stage IIIb to IV) nonsquamous NSCLC with measurable disease according to RECIST (version 1.1), ${ }^{14}$ Eastern Cooperative Oncology Group (ECOG) performance status (PS) of 0 or 1, and adequate bone marrow, liver, and kidney functions. Patients had to have received one or two prior systemic anticancer regimens, including prior platinum-based chemotherapy, without prior exposure to EGFR inhibitors, tivantinib, or any other MET inhibitor. Archival or fresh tissue samples for biomarker analyses and EGFR mutation status were mandatory for all patients. Patients with clinically unstable brain metastases or history of cardiac disease, uncontrolled hypertension, or other active malignancies were excluded.

\section{Study Design, Treatment, and Study Objectives}

The study was conducted according to the Declaration of Helsinki and approved by appropriate independent ethics committees or institutional review boards at all sites. Patients provided written informed consent before study participation and consent for tissue collection for biomarker assessment. An independent data monitoring committee periodically reviewed safety data and the interim analysis results.

After screening, patients were randomly assigned at a ratio of 1:1 to receive oral erlotinib $150 \mathrm{mg}$ once daily plus oral tivantinib $360 \mathrm{mg}$ twice daily $(\mathrm{E}+\mathrm{T})$ or oral erlotinib $150 \mathrm{mg}$ once daily plus matching placebo $(\mathrm{E}+\mathrm{P})$. Patients were stratified by number of prior therapies (one $v$ two), sex (male $v$ female), smoking history (never v ever), and EGFR and KRAS mutation status (mutant $v$ WT or unknown). Treatment continued until unacceptable toxicity, disease progression, or another discontinuation criterion was met. Tivantinib or erlotinib dose delays of $\leq 14$ days were permitted for grade $\geq 3$ nonhematologic toxicities until resolution to grade 1 or baseline, and treatment was reintroduced at a reduced dosage of one or both drugs depending on the toxicity. For hematologic toxicities of grade $\geq 3$ or platelet counts $<50 \times$ $10^{9} / \mathrm{L}$, tivantinib was withheld until absolute neutrophil and platelet counts returned to baseline ( $\geq 1.5 \times 10^{9} / \mathrm{L}$ and $\geq 100 \times 10^{9} / \mathrm{L}$, respectively).
The primary objective was OS in the intent-to-treat (ITT) population. Secondary objectives included OS in the EGFR WT subgroup, PFS in the ITT population, and safety. Exploratory analyses were performed for other predefined subgroups and efficacy parameters. Tumor response was assessed by investigators according to RECIST (version 1.1). ${ }^{14}$

\section{Statistical Analysis}

The study hypothesis was that $\mathrm{E}+\mathrm{T}$ would improve $\mathrm{OS}$ relative to $\mathrm{E}+$ $\mathrm{P}$ in the ITT population. For $90 \%$ power to detect a hazard ratio (HR) of 0.75 at a two-sided significance level of $0.01,735$ events were required. Assuming 18 months of enrollment, 12 additional months of follow-up, and a $9 \%$ rate of loss to follow-up, the target enrollment was 988 patients.

An interim analysis was planned after approximately $50 \%$ of planned events had occurred to allow early stopping for efficacy or futility. Stopping boundaries were determined using the Lan-DeMets family with O'BrienFleming parameters, ${ }^{15}$ while specifying nonbinding futility stopping boundaries. At the first interim efficacy analysis with 485 events, the one-sided $P$ value stopping boundaries were .00055 for efficacy stopping and .0743 for futility stopping.

OS and PFS were compared using stratified log-rank tests adjusting for number of prior therapies, sex, and smoking history. Kaplan-Meier estimates of the medians and corresponding 95\% CIs were determined. An unstratified Cox proportional hazards regression model was performed to obtain the point estimate of the HR and 95\% CI. Secondary efficacy end points were similarly analyzed. Safety was assessed by the investigator based on the incidence and severity of treatment-emergent adverse events (TEAEs) and their relationship to either treatment arm.

\section{Molecular Analyses}

Biomarkers in archival or fresh tumor samples were analyzed in the following order of priority: EGFR mutation, MET expression (determined by immunohistochemistry), KRAS mutation, and MET gene amplification when sufficient tumor tissue was available. Mutations in EGFR and KRAS were determined by polymerase chain reaction analysis using the Qiagen RotorGene (Qiagen, Hilden, Germany) at central laboratories (Covance, Indianapolis, IN; Geneva, Switzerland); existing mutation results were used if they were from accredited local laboratories. MET expression was analyzed at a central laboratory (LabCorp, Research Triangle Park, NC) using the SP44 rabbit monoclonal antibody (Ventana Medical Systems, Tucson, AZ). MET expression was defined as high if membranous staining intensity was $\geq 2$ in $\geq 50 \%$ of tumor cells. On the basis of limited MET epitope stability, MET analyses by immunohistochemistry must have been performed within 90 days of sectioning to be considered valid. MET gene copy number and chromosome 7 copy number were determined by fluorescence in situ hybridization using probes (LSI D7S486) for MET (7q31) and CEP7 (Abbott Molecular, Des Plaines, IL).

\section{RESULTS}

\section{Patient Population and Disposition}

Between January 2011 and July 2012 in Europe and Russia, the United States, Latin America, Canada, and Australia, 1,624 patients were screened, 576 failed to meet inclusion or exclusion criteria, and 1,048 were randomly assigned $(\mathrm{E}+\mathrm{T}, \mathrm{n}=526 ; \mathrm{E}+\mathrm{P}, \mathrm{n}=522 ;$ Fig 1$)$. Of these patients, 976 (93\%) subsequently discontinued study treatment, and two were lost to follow-up. The most common reason for treatment discontinuation was progressive disease $(\mathrm{E}+\mathrm{T}, \mathrm{n}=295$; $\mathrm{E}+\mathrm{P}, \mathrm{n}=350)$. Patients received study treatments for a mean of 16.2 weeks (range, 0.1 to 84.0 ) in the $\mathrm{E}+\mathrm{T}$ group and 13.9 weeks (range, 0.1 to 92.0 ) in the $\mathrm{E}+\mathrm{P}$ group.

The preplanned interim OS analysis was performed after 485 deaths, and the result crossed the protocol-defined stopping boundary for futility. Consequently, the independent data monitoring committee recommended study discontinuation, even though there were no 


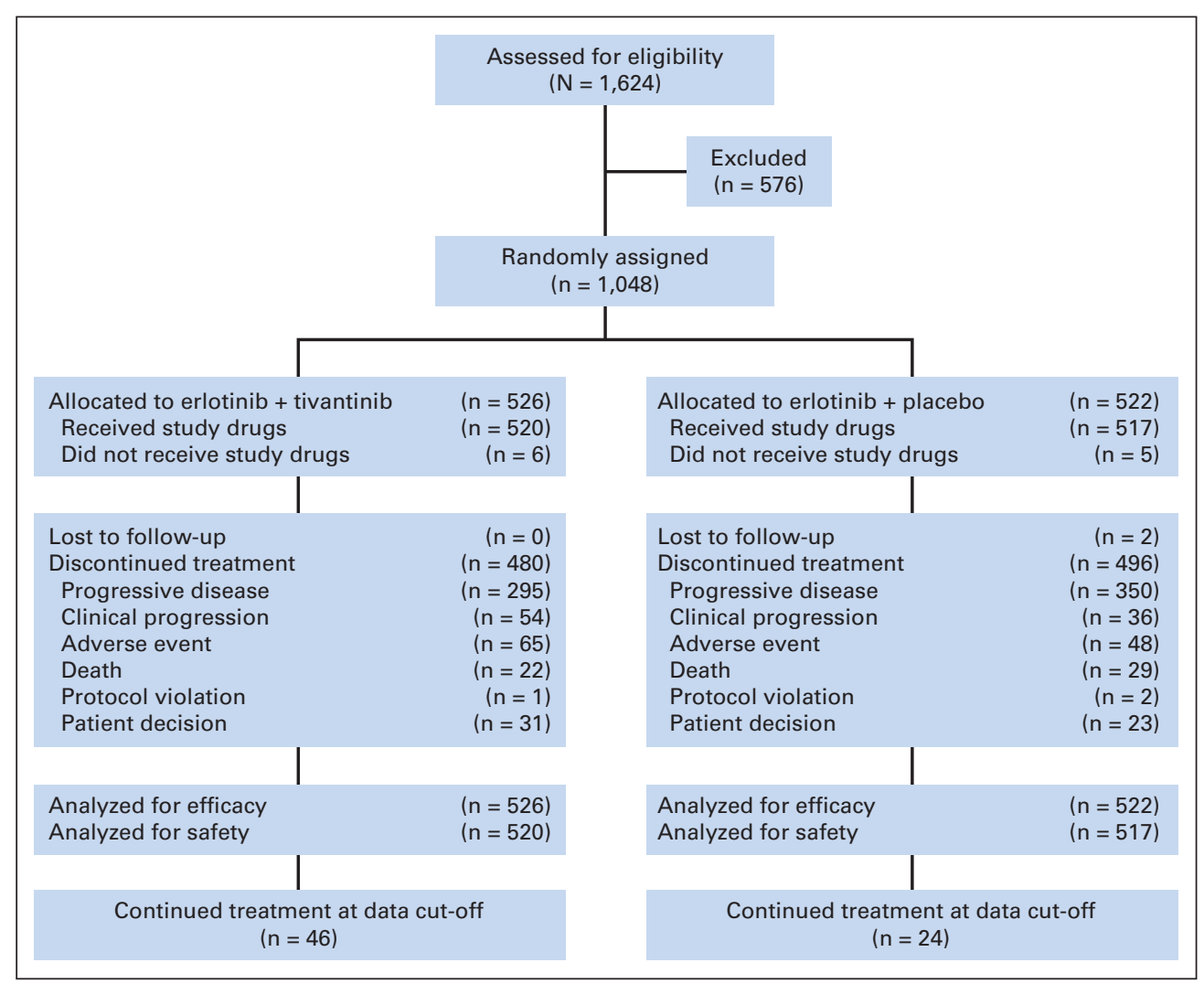

Fig 1. CONSORT diagram.

safety concerns, and PFS had improved. Blinding of treatment assignment was maintained, and patients receiving treatment were allowed to continue. A data cutoff was applied on December 15, 2012, at which time 614 survival events $(58.6 \%)$ had occurred $(\mathrm{E}+\mathrm{T}, \mathrm{n}=300$ [57.0\%]; $\mathrm{E}+\mathrm{P}, \mathrm{n}=314[60.2 \%])$. Results for the EGFR-mutant subpopulation were immature, and the study was continued for these patients and those receiving study treatment with clinical benefit.

\section{Patient Characteristics}

Among the 1,048 randomly assigned patients, treatment groups were well balanced for baseline demographics and clinical characteristics (Table 1). Median age was 62.0 years (range, 24 to 89 years); $59.1 \%$ of patients were men, $81.0 \%$ were either current or former smokers, 93.0\% had adenocarcinoma, and approximately two thirds had received only one prior systemic therapy.

Nearly all patients had EGFR mutation status determined, with 89.4\% having EGFR WT tumors (Table 2). Among 986 patients with known tumor KRAS mutation status, $28.8 \%$ were KRAS mutant. Of 1,048 randomly assigned patients, 445 tumor samples were investigated for MET expression by immunohistochemistry, and $47.4 \%$ of these had high expression. A total of 476 patients had samples evaluable for MET amplification assessment: 54 (11.3\%) had MET copy number $>4$, and four patients (two in each arm) had MET amplification with MET:CEP7 ratio $>2$. No patient had a MET:CEP7 ratio $>5$.

\section{Efficacy}

OS did not differ significantly between treatment groups in the ITT population ( $\mathrm{HR}, 0.98$; $95 \% \mathrm{CI}, 0.84$ to $1.14 ; P=.81$; Fig $2 \mathrm{~A}$ ).
Median OS was 8.5 versus 7.8 months for the $\mathrm{E}+\mathrm{T}$ and $\mathrm{E}+\mathrm{P}$ arms, respectively. Similarly, OS was not significantly different (median OS: $\mathrm{E}+\mathrm{T}, 7.2$ months; $\mathrm{E}+\mathrm{P}, 7.1$ months; HR, 1.00; 95\% CI, 0.85 to 1.18; $P=.94)$ within the EGFR WT subgroup, which comprised approximately $89.4 \%$ of the ITT population. In contrast to OS, tivantinib significantly increased median PFS in the ITT population (HR, 0.74; 95\% CI, 0.64 to $0.85 ; P<.001$ ) from 1.9 to 3.6 months (Fig $2 B$ ). In the EGFR WT subgroup, PFS was also significantly longer (HR, 0.72; 95\% $\mathrm{CI}, 0.62$ to $0.83 ; P<.001$ ) with $\mathrm{E}+\mathrm{T}$ than with $\mathrm{E}+\mathrm{P}$ (median PFS, $2.7 v 1.9$ months).

\section{Subgroup Analyses}

In the preplanned exploratory analysis of the subgroup of 211 patients with high MET tumor expression, a trend for OS benefit favoring $\mathrm{E}+\mathrm{T}$ was observed (median OS, $9.3 v 5.9$ months; HR, 0.70; 95\% CI, 0.49 to 1.01; Fig 3A). PFS also improved in the subgroup of patients with high MET expression (median, $3.7 v 1.9$ months; HR, 0.72; $95 \%$ CI, 0.52 to 0.99 ; Fig 3B). No association was observed between tivantinib treatment and other biomarker and demographic subgroups (Fig 4). Longer OS was observed in tumors with MET gene copy number $>4(\mathrm{HR}, 0.83 ; 95 \% \mathrm{CI}, 0.43$ to 1.61$)$, but the limited sample size precluded any meaningful conclusion. For the EGFRmutant subgroup $(\mathrm{n}=109)$, OS and PFS data at the cutoff time are still immature, with only 30 deaths.

EGFR and KRAS mutations were almost completely exclusive of each other, whereas MET expression was independent of EGFR and KRAS genotypes. Among fully defined molecular subgroups, the largest was EGFR WT, KRAS WT, and MET low $(\mathrm{n}=143)$, where OS did not improve (median OS: E + T, 7.5 months; E + P, 6.4 months; HR, 


\begin{tabular}{|c|c|c|}
\hline \multicolumn{3}{|c|}{$\begin{array}{l}\text { Table 1. Patient Baseline Demographic and Clinical Characteristics } \\
\text { (ITT population) }\end{array}$} \\
\hline Characteristic & $\begin{array}{c}\text { Erlotinib Plus } \\
\text { Tivantinib }(n=526) \\
\text { No. }(\%)\end{array}$ & $\begin{array}{c}\text { Erlotinib Plus } \\
\text { Placebo }(n=522) \\
\text { No. }(\%)\end{array}$ \\
\hline \multicolumn{3}{|l|}{ Age, years } \\
\hline Mean & 61.2 & 61.1 \\
\hline SD & 10.1 & 9.8 \\
\hline Median & 62.0 & 61.0 \\
\hline Range & $26-89$ & $24-87$ \\
\hline \multicolumn{3}{|l|}{ Sex } \\
\hline Female & $216(41.1)$ & $213(40.8)$ \\
\hline Male & $310(58.9)$ & $309(59.2)$ \\
\hline \multicolumn{3}{|l|}{ Race } \\
\hline White & $430(81.7)$ & 446 (85.4) \\
\hline Black & $16(3.0)$ & $12(2.3)$ \\
\hline Asian & $8(1.5)$ & $5(1.0)$ \\
\hline Other or not reported & $71(13.5)$ & $59(11.3)$ \\
\hline \multicolumn{3}{|l|}{ Smoker } \\
\hline Never & $101(19.2)$ & $98(18.8)$ \\
\hline Ever & 425 (80.8) & $424(81.2)$ \\
\hline Current & $98(18.6)$ & $97(18.6)$ \\
\hline Former & $327(62.2)$ & $327(62.6)$ \\
\hline \multicolumn{3}{|l|}{ ECOG PS } \\
\hline 0 & 168 (31.9) & $168(32.2)$ \\
\hline 1 & 357 (67.9) & $353(67.6)$ \\
\hline 2 & $1(0.2)$ & $1(0.2)$ \\
\hline \multicolumn{3}{|l|}{ Tumor stage at study entry } \\
\hline IIlb & $22(4.2)$ & $14(2.7)$ \\
\hline IV & 499 (94.9) & $501(96.0)$ \\
\hline Not reported & $5(1.0)$ & $7(1.3)$ \\
\hline \multicolumn{3}{|l|}{ NSCLC histologic type } \\
\hline Adenocarcinoma & 480 (91.3) & 495 (94.8) \\
\hline Large-cell carcinoma & $31(5.9)$ & $20(3.8)$ \\
\hline Other nonadenocarcinoma & $15(2.8)$ & $7(1.4)$ \\
\hline Unclassified nonadenocarcinoma & $7(1.3)$ & $3(0.6)$ \\
\hline \multicolumn{3}{|l|}{ Prior NSCLC radiotherapy } \\
\hline Yes & $232(44.1)$ & $219(42.0)$ \\
\hline No & 294 (55.9) & $303(58.0)$ \\
\hline \multicolumn{3}{|l|}{ Prior NSCLC surgery } \\
\hline Yes & $238(45.2)$ & $253(48.5)$ \\
\hline No & $288(54.8)$ & $269(51.5)$ \\
\hline \multicolumn{3}{|l|}{$\begin{array}{l}\text { No. of prior NSCLC systemic } \\
\text { therapies }\end{array}$} \\
\hline 1 & 346 (65.8) & $348(66.7)$ \\
\hline 2 & $180(34.2)$ & $174(33.3)$ \\
\hline Brain metastases & 66 (12.5) & $80(15.3)$ \\
\hline
\end{tabular}

1.09; 95\% CI, 0.72 to 1.65 ). In the EGFR WT, KRAS WT, and MET high subgroup $(\mathrm{n}=119)$, OS was prolonged for $\mathrm{E}+\mathrm{T}$ (median OS: $\mathrm{E}+\mathrm{T}, 8.8$ months; $\mathrm{E}+\mathrm{P}, 5.0$ months; HR, 0.56 ; $95 \% \mathrm{CI}, 0.35$ to 0.89 ).

\section{Response to Treatment}

The overall objective response rate (ORR) was 10.3\% (95\% CI, 8.0 to 13.2) with $\mathrm{E}+\mathrm{T}$ and $6.5 \%(95 \% \mathrm{CI}, 4.7$ to 9.0$)$ with $\mathrm{E}+\mathrm{P}$. The disease control rate (objective response plus stable disease) was $45.8 \%$ in patients receiving $\mathrm{E}+\mathrm{T}(95 \% \mathrm{CI}, 41.6$ to 50.1$)$ and $32.0 \%$ in those receiving $\mathrm{E}+\mathrm{P}$ (95\% CI, 28.1 to 36.1). Median duration of objective response was 40.4 weeks with $\mathrm{E}+\mathrm{T}$ and 47.9 weeks with $\mathrm{E}+\mathrm{P}$.

\begin{tabular}{|c|c|c|}
\hline & $\begin{array}{l}\text { Erlotinib Plus } \\
\text { Tivantinib }(n=526)\end{array}$ & $\begin{array}{c}\text { Erlotinib Plus } \\
\text { Placebo }(n=522) \\
\text { No. }(\%)\end{array}$ \\
\hline \multicolumn{3}{|c|}{$\overline{E G F R}$ mutation status } \\
\hline Mutant & $56(10.6)$ & $53(10.2)$ \\
\hline Wild type & $469(89.2)$ & $468(89.7)$ \\
\hline Unknown & $1(0.2)$ & $1(0.2)$ \\
\hline \multicolumn{3}{|c|}{ KRAS mutation status } \\
\hline Mutant & 136 (25.9) & $148(28.4)$ \\
\hline Wild type & $356(67.7)$ & $346(66.3)$ \\
\hline Unknown & $34(6.5)$ & $28(5.4)$ \\
\hline \multicolumn{3}{|c|}{ MET expression status } \\
\hline High & $104(19.8)$ & $107(20.5)$ \\
\hline Low & $107(20.3)$ & $127(24.3)$ \\
\hline Unknown & 315 (59.9) & $288(55.2)$ \\
\hline \multicolumn{3}{|l|}{ MET FISH status } \\
\hline Positive* & $27(5.1)$ & $27(5.2)$ \\
\hline Negative & $195(37.1)$ & 227 (43.5) \\
\hline Unknown & 304 (57.8) & 268 (51.3) \\
\hline
\end{tabular}

Abbreviations: FISH, fluorescent in situ hybridization; ITT, intent to treat; MET, mesenchymal-epithelial transition.

*MET gene copy number $\geq 4$.

\section{Postdiscontinuation Therapy}

After study treatments were discontinued, 192 (36.5\%) of 526 patients in the E + T group and 231 (44.3\%) of 522 in the E + P group received subsequent therapy, primarily chemotherapy $(\mathrm{E}+\mathrm{T}, 29.5 \%$; $\mathrm{E}+\mathrm{P}, 38.8 \%)$.

\section{Exploratory Multivariable Cox Regression}

A stepwise forward and backward model selection approach was taken in an exploratory multivariable Cox regression analysis with treatment retained in the model. Potential prognostic factors, including EGFR genotype, KRAS genotype, MET expression, age, baseline ECOG PS, sex, number of prior lines of therapy for NSCLC, smoking history, best response to prior therapy, and region, were fit into the Cox regression model along with the interaction with treatment. In the stepwise multivariable analysis, the final model for OS selected the following factors: EGFR genotype, best response to prior therapy, ECOG PS (and interaction), line of prior therapy, MET expression (and interaction), region, and smoking history. Notable interactions with treatment were observed, prompting closer examination of the subgroups (Fig 4).

\section{Safety}

In the safety population of 1,037 patients who received any dose of study drug, 1,016 (98.0\%) experienced at least one TEAE: 513 $(98.7 \%)$ in the $\mathrm{E}+\mathrm{T}$ group and $503(97.3 \%)$ in the $\mathrm{E}+\mathrm{P}$ group. The most common TEAEs in the $\mathrm{E}+\mathrm{T}$ versus $\mathrm{E}+\mathrm{P}$ group were fatigue or asthenia (43.5\% $v 38.1 \%$, respectively), diarrhea (34.6\% $v 41.0 \%)$, rash $(33.1 \% v 37.3 \%)$, and decreased appetite (29.0\% $v 28.8 \%$; Table 3). Myelosuppression, a known toxicity of tivantinib, was observed in this study. TEAEs related to myelosuppression for $\mathrm{E}+\mathrm{T}$ versus $\mathrm{E}+\mathrm{P}$ included anemia (16.0\% v 9.9\%), neutropenia (11.9\% v1.9\%), leukopenia $(5.8 \% v 1.0 \%)$, and febrile neutropenia $(3.3 \% v 0.4 \%)$. Grade $\geq$ 3 TEAEs were $8.5 \% v 0.8 \%$ for neutropenia and $6.3 \% v 2.9 \%$ for anemia, respectively. Eight patients developed interstitial lung disease (ILD; $\mathrm{E}+\mathrm{T}, \mathrm{n}=3 ; \mathrm{E}+\mathrm{P}, \mathrm{n}=5$ ). Bradycardia was reported in 14 


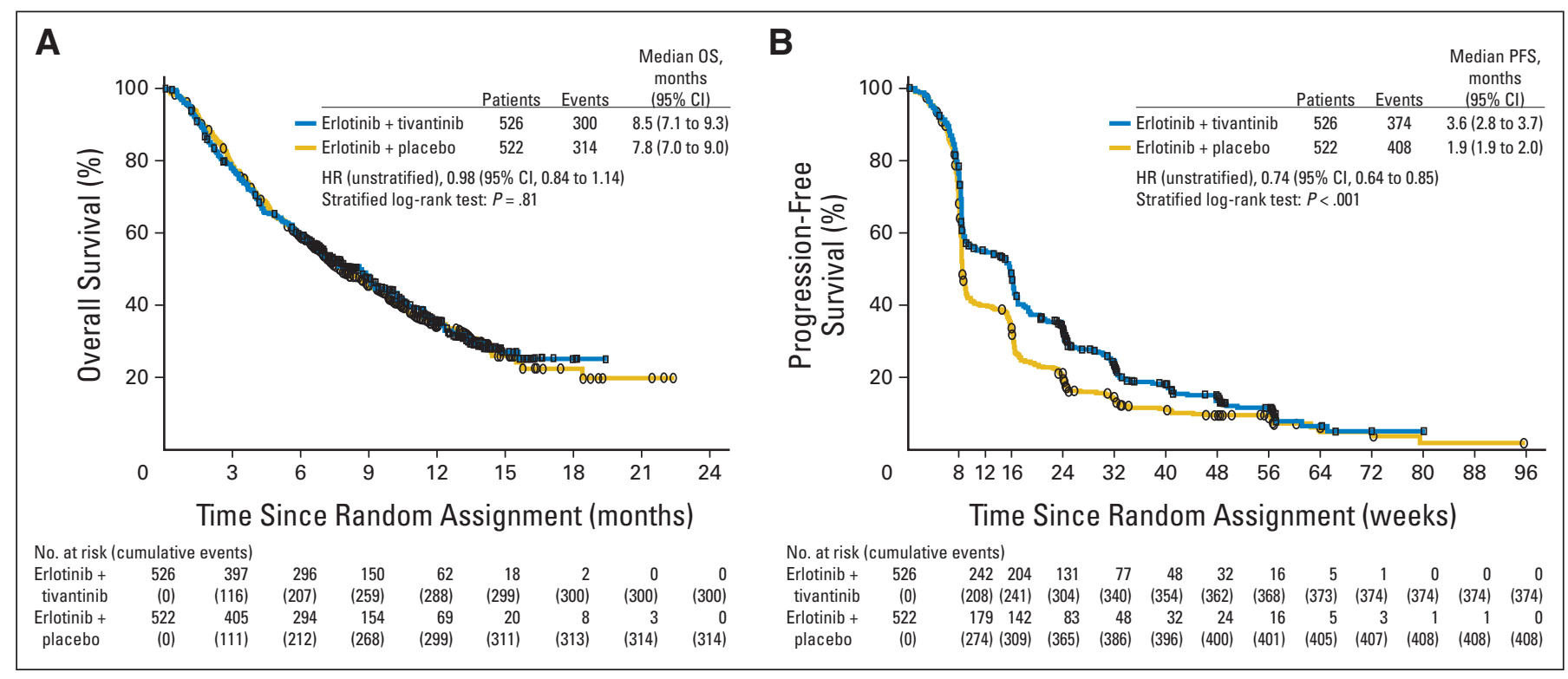

Fig 2. (A) Overall survival (OS) and (B) progression-free survival (PFS) for patients receiving erlotinib plus tivantinib versus erlotinib plus placebo (intent-to-treat population). HR, hazard ratio.

patients $(2.7 \%)$ receiving $\mathrm{E}+\mathrm{T}$ and none of the patients receiving $\mathrm{E}+$ $\mathrm{P}$; two cases in the $\mathrm{E}+\mathrm{T}$ group were grade $\geq 3$.

During the study, 614 patients (59.2\%) died, mainly as a result of disease progression (E + T, 46.0\%; E + P, 48.4\%). Of all deaths, 142 (13.7\% of safety population) were classified as TEAEs ( $\mathrm{E}+\mathrm{T}, 14.8 \%$; $\mathrm{E}+\mathrm{P}, 12.6 \%$ ), most related to underlying disease, leaving 66 deaths related to a TEAE other than disease progression $(\mathrm{E}+\mathrm{T}, 6.2 \%$; $\mathrm{E}+\mathrm{P}$, $6.6 \%)$. The most common reasons for death in these patients receiving $\mathrm{E}+\mathrm{T}$ versus $\mathrm{E}+\mathrm{P}$ were respiratory failure $(1.0 \% v 1.2 \%$, respectively), sepsis or septic shock $(1.0 \% v 0.2 \%)$, and pneumonia or bronchopneumonia $(0.6 \% v 1.0 \%)$. Five deaths $(1.0 \%)$ with $\mathrm{E}+\mathrm{T}$ and three deaths $(0.6 \%)$ with $\mathrm{E}+\mathrm{P}$ were considered associated with tivantinib or placebo. At least one serious adverse event (SAE) oc- curred in 410 patients $(\mathrm{E}+\mathrm{T}, 42.1 \%$; $\mathrm{E}+\mathrm{P}, 36.9 \%)$, the most common being respiratory events, as expected. Differences in SAE incidence between $\mathrm{E}+\mathrm{T}$ and $\mathrm{E}+\mathrm{P}$ treatment groups, respectively, were generally related to myelosuppression: anemia $(3.1 \% v 1.2 \%)$, febrile neutropenia $(2.9 \% v 0.4 \%)$, and neutropenia $(2.1 \% v 0.2 \%)$. There was also a higher incidence of the following SAEs with $\mathrm{E}+\mathrm{T}$ versus $\mathrm{E}+\mathrm{P}$, respectively: pneumonia $(3.8 \% v 2.1 \%)$ and sepsis $(1.0 \% v 0.4 \%)$.

\section{DISCUSSION}

This phase III study did not meet its primary end point of improved OS in previously treated patients with locally advanced or metastatic

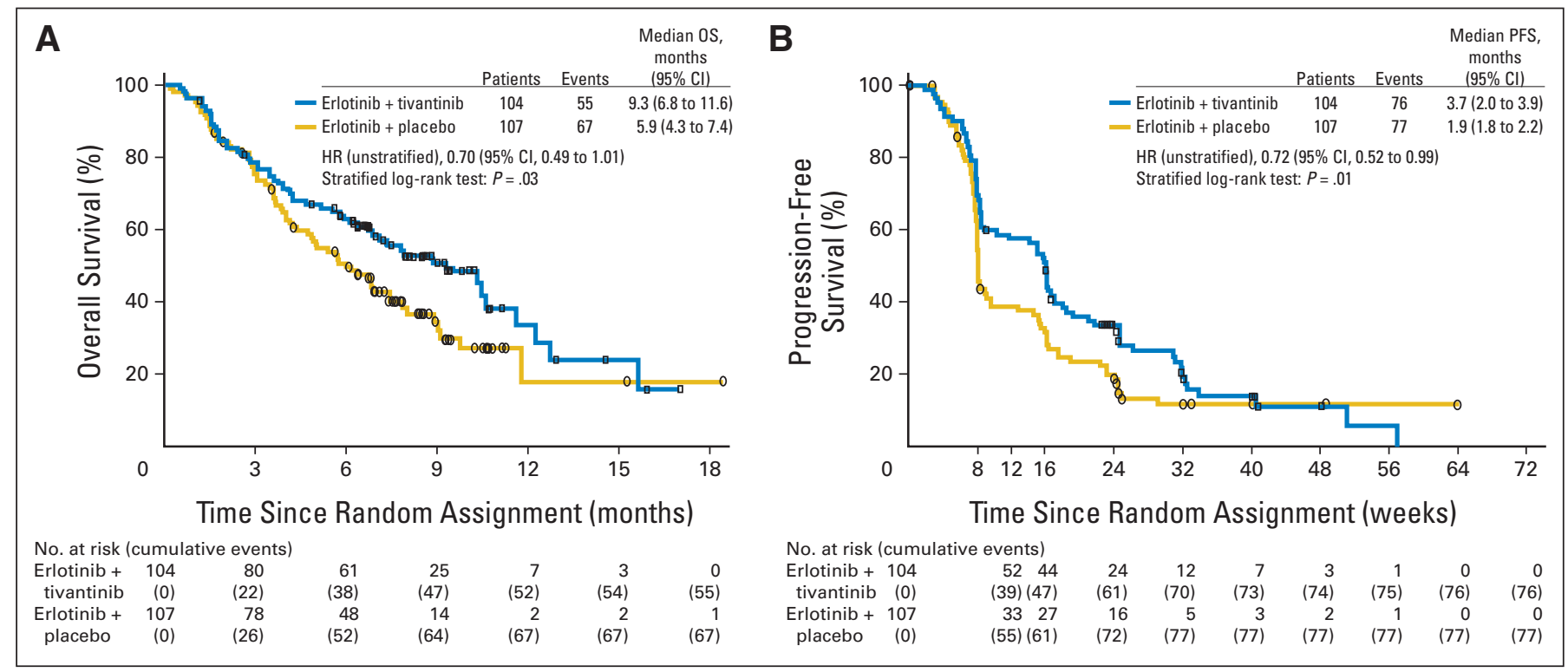

Fig 3. (A) Overall (OS) and (B) progression-free survival (PFS) for MET-high subgroup. HR, hazard ratio. 


\begin{tabular}{|c|c|c|c|c|c|c|}
\hline Factor & $\mathrm{n}$ & Hazard Ratio & $95 \% \mathrm{Cl}$ & & & \\
\hline All & 1,048 & 0.98 & 0.84 to 1.15 & & & \\
\hline \multicolumn{7}{|l|}{ EGFR } \\
\hline Mutant & 109 & 0.72 & 0.35 to 1.48 & & & \\
\hline Wild type & 937 & 1.00 & 0.85 to 1.18 & & & \\
\hline \multicolumn{7}{|l|}{ KRAS } \\
\hline Mutant & 284 & 1.04 & 0.78 to 1.40 & & & \\
\hline Wild type & 702 & 0.94 & 0.77 to 1.14 & & & \\
\hline Unknown & 62 & 1.46 & 0.69 to 3.07 & & & $-\sqrt{-}$ \\
\hline \multicolumn{7}{|l|}{ MET } \\
\hline High & 211 & 0.70 & 0.49 to 1.01 & & & \\
\hline Low & 234 & 0.90 & 0.64 to 1.26 & & & \\
\hline Unknown & 603 & 1.13 & 0.92 to 1.39 & & & 一 \\
\hline \multicolumn{7}{|l|}{ ECOG PS } \\
\hline 0 & 336 & 0.78 & 0.57 to 1.07 & & & \\
\hline 1 & 710 & 1.10 & 0.91 to 1.32 & & & - \\
\hline \multicolumn{7}{|l|}{ Age, years } \\
\hline$<65$ & 646 & 0.84 & 0.69 to 1.03 & & & \\
\hline$\geq 65$ & 402 & 1.27 & 0.98 to 1.64 & & & \\
\hline \multicolumn{7}{|l|}{ Sex } \\
\hline Female & 429 & 0.87 & 0.68 to 1.13 & & & \\
\hline Male & 619 & 1.06 & 0.86 to 1.29 & & & \\
\hline \multicolumn{7}{|c|}{ Previous regimen } \\
\hline 1 & 694 & 0.95 & 0.78 to 1.16 & & & \\
\hline \multirow[t]{3}{*}{2} & 354 & 1.03 & 0.79 to 1.34 & & & \\
\hline & & & & 0.5 & 1.0 & 2.0 \\
\hline & & & & Favors tivantinib & & Favors placebo \\
\hline
\end{tabular}

Fig 4. Forest plot of overall survival hazard ratio by predefined subgroups. ECOG PS, Eastern Cooperative Group performance status; MET, mesenchymalepithelial transition expression. nonsquamous NSCLC, although significant improvement in PFS and increased ORR were observed. In addition, an exploratory analysis indicated OS and PFS benefit with tivantinib in the subgroup of patients with MET-high status by immunohistochemistry. In the subgroup of patients with tumor MET gene copy number $>4$, there was no difference in OS between treatment groups, but only four patients had selective MET amplification with a MET:CEP7 ratio > 2. Although the drugs were well tolerated, the survival benefit may have been diminished by the associated adverse events (AEs), such as asthenia or fatigue and neutropenia.

\begin{tabular}{|c|c|c|c|c|}
\hline \multicolumn{5}{|c|}{$\begin{array}{l}\text { Table 3. Treatment-Emergent AEs in } \geq 15 \% \text { of Patients in Either } \\
\text { Treatment Group }\end{array}$} \\
\hline \multirow[b]{2}{*}{$\mathrm{AE}$} & \multicolumn{2}{|c|}{$\begin{array}{c}\text { Erlotinib Plus Tivantinib } \\
(n=520) \\
\text { No. }(\%)\end{array}$} & \multicolumn{2}{|c|}{$\begin{array}{c}\text { Erlotinib Plus Placebo } \\
(n=517) \\
\text { No. }(\%)\end{array}$} \\
\hline & All Grades & Grade $\geq 3$ & All Grades & Grade $\geq 3$ \\
\hline Fatigue or asthenia & $226(43.5)$ & $47(9.0)$ & $197(38.1)$ & $41(7.9)$ \\
\hline Diarrhea & 180 (34.6) & $13(2.5)$ & $212(41.0)$ & $19(3.7)$ \\
\hline Rash & $172(33.1)$ & $10(1.9)$ & $193(37.3)$ & $20(3.9)$ \\
\hline Decreased appetite & $151(29.0)$ & $15(2.9)$ & 149 (28.8) & $15(2.9)$ \\
\hline Dyspnea & $136(26.2)$ & $46(8.8)$ & $117(22.6)$ & $38(7.4)$ \\
\hline Nausea & $121(23.3)$ & $4(0.8)$ & $123(23.8)$ & $9(1.7)$ \\
\hline Cough & $110(21.2)$ & $6(1.2)$ & $91(17.6)$ & $4(0.8)$ \\
\hline Dermatitis acneiform & $90(17.3)$ & $7(1.3)$ & $98(19.0)$ & $11(2.1)$ \\
\hline Vomiting & $73(14.0)$ & $5(1.0)$ & $81(15.7)$ & $6(1.2)$ \\
\hline Anemia & $83(16.0)$ & $33(6.3)$ & $51(9.9)$ & $15(2.9)$ \\
\hline
\end{tabular}

In another recent phase III trial of tivantinib plus erlotinib compared with tivantinib plus placebo in previously treated Asian patients with nonsquamous NSCLC and EGFR WT, OS and PFS were also numerically prolonged in patients receiving tivantinib. However, the study was discontinued early because of toxicity concerns related to the incidence of ILD - a known AE observed in Japanese patients treated with EGFR inhibitors - in the tivantinib plus erlotinib group. ${ }^{16}$ In our study, which did not include Asian patients, the combination of tivantinib plus erlotinib was generally well tolerated. AE profiles were similar between treatment groups, with the exception of more frequent neutropenia and anemia with tivantinib. The combination of tivantinib with erlotinib did not increase the known risk of ILD associated with erlotinib. ${ }^{17}$

Aberrant activation of the hepatocyte growth factor/MET signaling pathway through MET gene amplification and/or high MET protein expression is known to occur in many solid tumors. ${ }^{6,18}$ Phase I and II studies of tivantinib as monotherapy or in combination with other agents in patients with different tumor types, including NSCLC, have indicated a potential benefit for tivantinib and possible roles of MET protein expression, MET amplification, and KRAS mutation as predictive markers of efficacy. ${ }^{12,19-24}$ Although our phase III study did not meet its primary end point, the data suggest a potential benefit in patients with high MET expression, consistent with the hypothesis that MET expression could be a potential biomarker for activity in this setting. Recent in vitro studies have reported that tivantinib has activity against cells that harbor little or undetectable levels of MET, suggesting additional mechanisms of action, including tubulin inhibition ${ }^{25-27}$ or the possible involvement of cellular mechanisms ${ }^{28}$ and signaling pathways activated by MET. ${ }^{29}$ Although it is unclear the 
effect that such activity may have in the clinical setting, data from this and other randomized phase II trials demonstrate that tivantinib has greater survival benefit in patients with high MET expression. ${ }^{19,23}$

Several other agents have shown efficacy in patients with specific molecular aberrations in NSCLC. Crizotinib, an oral tyrosine kinase inhibitor of MET, is indicated for the treatment of anaplastic lymphoma kinase-positive metastatic NSCLC. ${ }^{30-32}$ It has also demonstrated antitumor activity in a small group of patients with METamplified advanced NSCLC, defined as selective gene amplification with MET:CEP7 ratio $\geq 1.8$ to $\leq 2.2$ (low), $>2.2$ to $<5$ (intermediate), and $\geq 5$ (high). ${ }^{33,34}$ In comparison, only four patients in our study had selective $M E T$ gene amplification with a MET:CEP7 ratio $\geq$ 2.0, and only one had a ratio $>3.0$.

Onartuzumab - a monovalent monoclonal antibody targeting the MET receptor - in combination with erlotinib in a phase II study of patients with advanced NSCLC with high MET expression by immunohistochemistry improved OS and PFS. ${ }^{35}$ However, a subsequent randomized phase III trial performed in patients with advanced NSCLC with high MET expression was stopped early for futility. ${ }^{36}$ The determination of high MET expression in both onartuzumab studies seemed to be generally similar (immunohistochemistry staining intensity $\geq 2$ in $\geq 50 \%$ of tumor cells using SP44 antibody), but some methodologic details are unavailable. ${ }^{35,36}$ As additional investigations of targeted agents are conducted in patients with MET-high NSCLC, an appropriate definition of MET-high status will be critical to identify those patients who will benefit most from MET-targeted therapies.

In summary, the addition of tivantinib to erlotinib was well tolerated but did not improve survival in the overall population of patients with nonsquamous NSCLC, although PFS and ORR were improved. Further investigation of tivantinib in patients with nonsquamous NSCLC with high MET expression is warranted, as is exploration of the most relevant tumor biomarkers to select patients for combined MET and EGFR inhibition therapy.

\section{AUTHORS' DISCLOSURES OF POTENTIAL CONFLICTS OF INTEREST}

Disclosures provided by the authors are available with this article at www.jco.org.

\section{AUTHOR CONTRIBUTIONS}

Conception and design: Giorgio Scagliotti, Silvia Novello, Lecia V. Sequist, Alan Sandler, Jeffrey S. Ross, Qiang Wang, Reinhard von Roemeling, Brian Schwartz

Provision of study materials or patients: Joachim von Pawel, Silvia Novello, Rodryg Ramlau, Adolfo Favaretto, Fabrice Barlesi, Sergey Orlov, David Spigel, Vera Hirsh, Frances A. Shepherd, Lecia V. Sequist, Alan Sandler

Collection and assembly of data: Giorgio Scagliotti, Joachim von Pawel, Rodryg Ramlau, Adolfo Favaretto, Fabrice Barlesi, Sergey Orlov, Vera Hirsh, Frances A. Shepherd, Jeffrey S. Ross, Qiang Wang, Dale Shuster, Brian Schwartz

Data analysis and interpretation: Giorgio Scagliotti, Silvia Novello, Rodryg Ramlau, Wallace Akerley, Sergey Orlov, Armando Santoro, David Spigel, Vera Hirsh, Frances A. Shepherd, Lecia V. Sequist, Jeffrey S. Ross, Qiang Wang, Reinhard von Roemeling, Dale Shuster, Brian Schwartz

Manuscript writing: All authors

Final approval of manuscript: All authors

\section{REFERENCES}

1. World Health Organization: GLOBOCAN 2012: Estimated Cancer Incidence, Mortality and Prevalence Worldwide in 2012. Lyon, France, International Agency for Research on Cancer, 2012

2. American Cancer Society: Cancer Facts \& Figures 2012. Atlanta, GA, American Cancer Society, 2012

3. NSCLC Meta-Analyses Collaborative Group: Chemotherapy in addition to supportive care improves survival in advanced non-small-cell lung cancer: A systematic review and meta-analysis of individual patient data from 16 randomized controlled trials. J Clin Oncol 26:4617-4625, 2008

4. Feng $Y, M a P C$ : MET targeted therapy for lung cancer: Clinical development and future directions. Lung Cancer (Auckl) 3:53-67, 2012

5. Peters S, Adjei AA: MET: A promising anticancer therapeutic target. Nat Rev Clin Oncol 9:314326, 2012

6. Scagliotti GV, Novello S, von Pawel J: The emerging role of MET/HGF inhibitors in oncology. Cancer Treat Rev 39:793-801, 2013

7. Eathiraj S, Palma R, Volckova E, et al: Discovery of a novel mode of protein kinase inhibition characterized by the mechanism of inhibition of human mesenchymal-epithelial transition factor (cMET) protein autophosphorylation by ARQ 197. J Biol Chem 286:20666-20676, 2011

8. Munshi N, Jeay $S$, Li $Y$, et al: ARQ 197, a novel and selective inhibitor of the human c-Met receptor tyrosine kinase with antitumor activity. Mol Cancer Ther 9:1544-1553, 2010
9. Ludovini V, Bianconi F, Pistola L, et al: Optimization of patient selection for EGFR- TKIs in advanced non-small cell lung cancer by combined analysis of KRAS, PIK3CA, MET, and non-sensitizing EGFR mutations. Cancer Chemother Pharmacol 69: 1289-1299, 2012

10. Cappuzzo F, Ciuleanu $T$, Stelmakh $L$, et al: Erlotinib as maintenance treatment in advanced non-small-cell lung cancer: A multicentre, randomised, placebo-controlled phase 3 study. Lancet Oncol 11:521-529, 2010

11. Shepherd FA, Rodrigues Pereira J, Ciuleanu $T$, et al: Erlotinib in previously treated non-small-cell lung cancer. N Engl J Med 353:123-132, 2005

12. Sequist LV, von Pawel J, Garmey EG, et al: Randomized phase II study of erlotinib plus tivantinib versus erlotinib plus placebo in previously treated non-small-cell lung cancer. J Clin Oncol 29:3307-3315, 2011

13. Scagliotti GV, Novello S, Schiller JH, et al: Rationale and design of MARQUEE: A phase III, randomized, double-blind study of tivantinib plus erlotinib versus placebo plus erlotinib in previously treated patients with locally advanced or metastatic, nonsquamous, non-small-cell lung cancer. Clin Lung Cancer 13:391-395, 2012

14. Eisenhauer EA, Therasse $P$, Bogaerts J, et al: New response evaluation criteria in solid tumours: Revised RECIST guideline (version 1.1). Eur J Cancer 45:228-247, 2009

15. Lan KKG, DeMets DL: Discrete sequential boundaries for clinical trials. Biometrika 70:659-663, 1983

16. Azuma $K$, Yoshioka $H$, Yamamoto $N$, et al: Tivantinib plus erlotinib versus placebo plus erlotinib in Asian patients with previously treated nonsquamous NSCLC with wild-type EGFR: First report of a phase III ATTENTION trial. J Clin Oncol 32:516s, 2014 (suppl 15s; abstr 8044)

17. Tarceva (erlotinib): Prescribing information. San Francisco, CA, Genentech, 2014

18. Cui JJ: Targeting receptor tyrosine kinase MET in cancer: Small molecule inhibitors and clinical progress. J Med Chem 57:4427-4453, 2014

19. Eng $C$, Bendell J, Bessudo $A$, et al: Phase I results of the randomized, placebo controlled, phase I/II study of the novel oral c-Met inhibitor, ARQ 197, irinotecan (CPT-11), and cetuximab (C) in patients (pts) with wild-type (WT) KRAS metastatic colorectal cancer (mCRC) who have received front-line systemic therapy. J Clin Oncol 29:241s, 2011 (suppl; abstr 3582)

20. Goldman JW, Laux I, Chai F, et al: Phase 1 dose-escalation trial evaluating the combination of the selective MET (mesenchymal-epithelial transition factor) inhibitor tivantinib (ARO 197) plus erlotinib. Cancer 118:5903-5911, 2012

21. Kang $Y K$, Muro K, Ryu MH, et al: A phase II trial of a selective c-Met inhibitor tivantinib (ARO 197) monotherapy as a second- or third-line therapy in the patients with metastatic gastric cancer. Invest New Drugs 32:355-361, 2014

22. Rimassa L, Personeni N, Simonelli M, et al: Tivantinib: A new promising mesenchymal-epithelial transition factor inhibitor in the treatment of hepatocellular carcinoma. Future Oncol 9:153-165, 2013

23. Santoro A, Rimassa $L$, Borbath I, et al: Tivantinib for second-line treatment of advanced hepatocellular 
carcinoma: A randomised, placebo-controlled phase 2 study. Lancet Oncol 14:55-63, 2013

24. Yamamoto $\mathrm{N}$, Murakami $\mathrm{H}$, Hayashi $\mathrm{H}$, et al: CYP2C19 genotype-based phase I studies of a c-Met inhibitor tivantinib in combination with erlotinib, in advanced/metastatic non-small cell lung cancer. Br J Cancer 109:2803-2809, 2013

25. Basilico C, Pennacchietti S, Vigna $E$, et al: Tivantinib (ARQ197) displays cytotoxic activity that is independent of its ability to bind MET. Clin Cancer Res 19:2381-2392, 2013

26. Calles A, Kwiatkowski N, Cammarata BK, et al: Tivantinib (ARO 197) efficacy is independent of MET inhibition in non-small-cell lung cancer cell lines. Mol Oncol, 9:260-269, 2015

27. Katayama R, Aoyama A, Yamori T, et al: Cytotoxic activity of tivantinib (ARQ 197) is not due solely to c-MET inhibition. Cancer Res 73:3087-3096, 2013
28. Remsing Rix LL, Kuenzi BM, Luo $Y$, et al: GSK3 alpha and beta are new functionally relevant targets of tivantinib in lung cancer cells. ACS Chem Biol 9:353-358, 2014

29. Kanteti R, Dhanasingh I, Kawada I, et al: MET and PI3K/mTOR as a potential combinatorial therapeutic target in malignant pleural mesothelioma. PLoS One 9:e105919, 2014

30. Xalkori (crizotinib): Prescribing information. New York, NY, Pfizer, 2014

31. Forde PM, Rudin CM: Crizotinib in the treatment of non-small-cell lung cancer. Expert Opin Pharmacother 13:1195-1201, 2012

32. Shaw AT, Kim DW, Nakagawa $K$, et al: Crizotinib versus chemotherapy in advanced ALK-positive lung cancer. N Engl J Med 368:2385-2394, 2013

33. Camidge DR, Bang YJ, Kwak EL, et al: Activity and safety of crizotinib in patients with ALK-positive non-small-cell lung cancer: Updated results from a phase 1 study. Lancet Oncol 13:1011-1019, 2012

34. Camidge DR, Ou SI, Shapiro GI, et al: Efficacy and safety of crizotinib in patients with advanced c-MET-amplified non-small cell lung cancer (NSCLC). J Clin Oncol 32:506s, 2014 (suppl 15s; abstr 8001)

35. Spigel DR, Ervin TJ, Ramlau RA, et al: Randomized phase II trial of Onartuzumab in combination with erlotinib in patients with advanced non-small-cell lung cancer. J Clin Oncol 31:41054114, 2013

36. Spigel DR, Edelman M, O'Byrne K, et al: Onartuzumab plus erlotinib versus erlotinib in previously treated stage IIIb or IV NSCLC: Results from the pivotal phase III randomized, multicenter, placebocontrolled METLung (OAM4971g) global trial. J Clin Oncol 32:506s, 2014 (suppl 15s; abstr 8000)

\section{Support}

Supported by ArQule and Daiichi Sankyo (Tokyo, Japan), which also funded editorial support provided by inScience Communications, Springer Healthcare.

\section{ASCO Answers Guides to Breast, Colorectal, Prostate, and Lung Cancers}

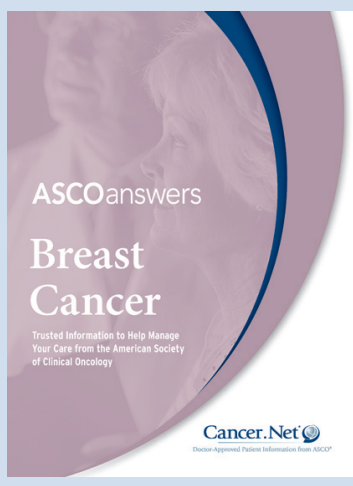

ASCO Answers guides to cancer are designed to help patients newly diagnosed with cancer understand their disease and treatment options. These comprehensive, patient-friendly booklets contain trusted information about diagnosis, treatment, side effects, and the psychosocial effects of cancer. They also provide space for patients to record details about their diagnosis and treatment plan, a feature that allows patients to easily go back and find the most pertinent information when needed. Each guide can be purchased from the ASCO University Bookstore at www.cancer.net/estore, with a 20\% discount for ASCO members and free shipping.

\section{ASC(1) \\ American Society of Clinical Oncology}




\section{AUTHORS' DISCLOSURES OF POTENTIAL CONFLICTS OF INTEREST}

Phase III Multinational, Randomized, Double-Blind, Placebo-Controlled Study of Tivantinib (ARQ 197) Plus Erlotinib Versus Erlotinib Alone in Previously Treated Patients With Locally Advanced or Metastatic Nonsquamous Non-Small-Cell Lung Cancer

The following represents disclosure information provided by authors of this manuscript. All relationships are considered compensated. Relationships are self-held unless noted. I = Immediate Family Member, Inst = My Institution. Relationships may not relate to the subject matter of this manuscript. For more information about ASCO's conflict of interest policy, please refer to www.asco.org/rwc or jco.ascopubs.org/site/ifc.

\section{Giorgio Scagliotti}

Honoraria: AstraZeneca, Clovis Oncology, Eli Lilly, Pfizer, Roche Consulting or Advisory Role: Eli Lilly

Speakers' Bureau: AstraZeneca, Eli Lilly, Pfizer

Joachim von Pawel

Consulting or Advisory Role: Daiichi Sankyo, Pfizer, Clovis Oncology, Novartis, AbbVie, Teva, Bristol-Myers Squibb

Silvia Novello

Consulting or Advisory Role: MSD, Boehringer Ingelheim, Novartis, Eli Lilly, AstraZeneca

\section{Rodryg Ramlau}

Honoraria: Eli Lilly, Boehringer Ingelheim, Roche, MSD

Consulting or Advisory Role: Eli Lilly, Boehringer Ingelheim, Roche, MSD

Speakers' Bureau: Eli Lilly, Boehringer Ingelheim

Travel, Accommodations, Expenses: Eli Lilly, Boehringer Ingelheim, Roche, MSD

\section{Adolfo Favaretto}

No relationship to disclose

\section{Fabrice Barlesi}

Honoraria: Eli Lilly, Pfizer, Novartis, AstraZeneca, Genentech/Roche, GlaxoSmithKline, Pierre Fabre Medicament

Consulting or Advisory Role: Genentech/Roche

Research Funding: Bayer (Inst), Genentech/Roche (Inst), Eli

Lilly/ImClone (Inst), GlaxoSmithKline (Inst), AstraZeneca/MedImmune

(Inst), Boehringer Ingelheim (Inst), Pfizer (Inst), Bristol-Myers Squibb

(Inst), Novartis (Inst), Merck (Inst), Eisai (Inst), Daiichi Sankyo (Inst)

Travel, Accommodations, Expenses: Genentech/Roche, Novartis, Eli

Lilly, Novartis

Wallace Akerley

Travel, Accommodations, Expenses: Daiichi Sankyo, Genentech, Clovis Oncology, Peregrine, Bristol-Myers Squibb

\section{Sergey Orlov}

No relationship to disclose

\section{Armando Santoro}

No relationship to disclose

David Spigel

No relationship to disclose

Vera Hirsh

Consulting or Advisory Role: Daiichi Sankyo
Frances A. Shepherd

Stock or Other Ownership: Eli Lilly, AstraZeneca

Honoraria: Eli Lilly, AstraZeneca, Bristol-Myers Squibb, Merck Serono, Roche/Genentech, Merck/Schering Plough, Boeringher Ingelheim Consulting or Advisory Role: Eli Lilly, AstraZeneca, GlaxoSmithKline, Boeringher Ingelheim

Research Funding: Boeringher Ingelheim (Inst)

Travel, Accommodations, Expenses: Novartis

\section{Lecia V. Sequist}

Consulting or Advisory Role: Clovis Oncology, Novartis, Merrimack Pharmaceuticals, AstraZeneca, Genentech, Taiho Pharmaceutical, Boehringer Ingelheim

Research Funding: Boehringer Ingelheim (Inst), Clovis Oncology (Inst), Genentech (Inst), Merrimack Pharmaceuticals (Inst), GlaxoSmithKline (Inst), ArQule (Inst), Daiichi Sankyo (Inst), Novartis (Inst), AstraZeneca (Inst), Johnson \& Johnson (Inst), Eli Lilly (Inst), Merck (Inst), Taiho Pharmaceutical (Inst)

\section{Alan Sandler}

Employment: Genentech/Roche

Stock or Other Ownership: Roche

Honoraria: Genentech/Roche, Eli Lilly, Pfizer, GlaxoSmithKline, Johnson \& Johnson, Boehringer Ingelheim

Consulting or Advisory Role: Genentech/Roche, Johnson \& Johnson, Boehringer Ingelheim, Eli Lilly, GlaxoSmithKline, Amgen, Pfizer Speakers' Bureau: Eli Lilly, Pfizer, Genentech/Roche Research Funding: ArQule

Jeffrey S. Ross

Employment: Foundation Medicine

Leadership: Foundation Medicine

Stock or Other Ownership: Foundation Medicine

Honoraria: Genentech/Roche, Pfizer, Bristol-Myers Squibb

Research Funding: Foundation Medicine

\section{Qiang Wang}

Employment: Daiichi Sankyo

Reinhard von Roemeling

Employment: Daiichi Sankyo

Dale Shuster

Employment: Daiichi Sankyo

Stock or Other Ownership: Daiichi Sankyo

Brian Schwartz

Employment: ArQule

Leadership: ArQule

Stock or Other Ownership: ArQule 


\section{Acknowledgment}

We thank all of the study participants and their families, the clinical investigators and site staff, and the data monitoring committee members (Paul Bunn, Thomas Fleming, Nicholas Thatcher). We also thank Joan Schiller, MD, and Professor JeanCharles Soria, who provided advice during the study; Anila Qureshi, who provided medical support; Hamim Zahir, who provided clinical pharmacology and biomarker support; Peter McCroskery, who provided safety oversight; and Jane Diamond, who provided operational support. Yvonne E. Yarker, PhD, CMPP, and Robert Schupp, PharmD, CMPP, of inScience Communications, Springer Healthcare, provided medical writing support funded by Daiichi Sankyo.

Presented as an oral/poster presentation at the European Cancer Congress, Amsterdam, the Netherlands, September 27-October 1, 2013, and the International Association for the Study of Lung Cancer 15th World Conference on Lung Cancer, Sydney, New South Wales, Australia, October 27-30, 2013. 